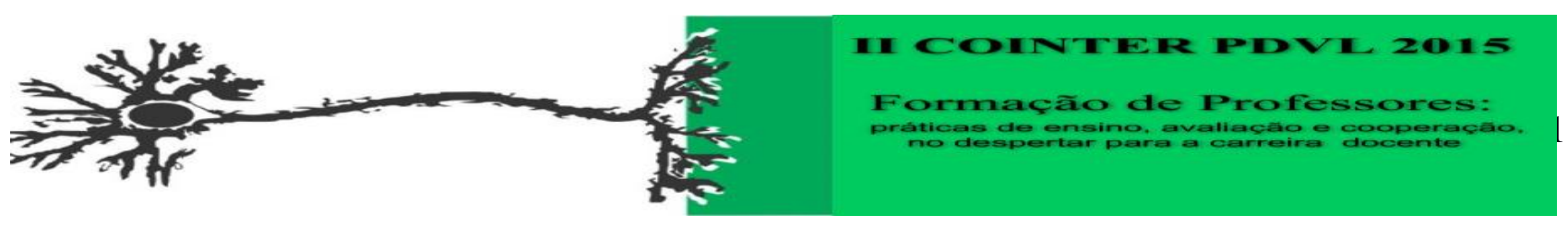

\title{
FORMAÇÃO DE PROFESSORES DE FÍSICA: UMA DISCUSSÃO SOBRE A PRÁTICA DOCENTE
}

\author{
Apresentação: Relato de Experiência
}

Zaidilma dos Santos Santana ${ }^{1}$; Ana Paula de Oliveira Aires ${ }^{2}$; Marina Nunes de Oliveira ${ }^{3}$; Albertina Marília Alves Guedes ${ }^{4}$.

\section{Introdução}

De acordo com os Parâmetros Curriculares Nacionais (BRASIL, 1999) os professores do curso de Licenciatura em Física devem desenvolver, em sala de aula, metodologias de ensino que permita ao estudante construir uma visão crítica e reflexiva dos conteúdos estudados na formação do cidadão contemporâneo, atuante e solidário o qual possa compreender, intervir e participar no contexto social da realidade escolar. Todavia, conforme apresenta Shigunov e Maciel (1997), as metodologias de ensino utilizadas na formação de professores nos cursos de licenciaturas ainda privilegiam o modelo tradicional em detrimento das metodologias de ensino que possibilitam a participação dos estudantes de modo ativo, participativo e autônomo. Por isso, os conteúdos ministrados são assimilados pelos estudantes de modo fragmentado e descontextualizado (CANDAU, 1997).

\section{Relato de Experiência}

Esse trabalho refere-se a um Relato de Experiência vivenciado pelas pesquisadoras e quatro professores da área pedagógica e da área de exatas do curso de Licenciatura em Física do IF Sertão PE. Considerando que os professores dos cursos de Licenciatura em Física devem atuar, em sala de aula, com metodologias de ensino que possibilite aos alunos construírem uma visão crítica e reflexiva sobre os conteúdos estudados relacionando os conteúdos teóricos com atividades práticas contextualizadas com a realidade social (BRASIL, 1999).

A questão que norteou a entrevista com os participantes foi: Para você professor, qual é a relação entre as metodologias de ensino apreendidas durante a sua formação docente e as metodologias de ensino que você desenvolve em sala de aula enquanto professor no curso de Licenciatura em Física do IF Sertão PE, Campus Petrolina? As Entrevistas Abertas foram realizadas com o uso de um aparelho de áudio as quais foram posteriormente transcritas (MACEDO, 2009).

\footnotetext{
${ }^{1}$ Estudante do Curso de Licenciatura em Física. IF Sertão PE, Campus Petrolina. E-mail: zaidilmass@gmail.com ${ }^{2}$ Estudante do Curso de Licenciatura em Física. IF Sertão PE, Campus Petrolina. E-mail: paulinhaah05@gmail.com ${ }^{3}$ Estudante do Curso de Licenciatura em Física. IF Sertão PE, Campus Petrolina. E-mail: marina.mno@hotmail.com ${ }^{4}$ Professora do curso de Licenciatura em Física. IF Sertão PE, Campus Petrolina. E-mail: albertinamarilia@hotmail.com
} 
Após a transcrição das entrevistas foi possível perceber que, para os professores que ministram disciplinas da área pedagógica "os alunos do curso de Licenciatura em Física do IF Sertão PE, Campus Petrolina, tem uma visão muito técnica dos conteúdos estudados em sala de aula e, por isso, não valorizam os conteúdos pedagógicos que são ministrados pelos professores desta área do conhecimento”. Além disso, conforme revelado por outro professor da área pedagógica, “os alunos tem certa resistência com a parte pedagógica e psicológica visto que não pensam sobre sua futura prática enquanto professor”. Ainda outro professor da área pedagógica ainda relatou que, na verdade, "existe um problema de falta de comunicação entre os próprios professores do curso". Esse mesmo professor acrescentou também que "as turmas do curso de Licenciatura em Física não são resistentes (as disciplinas pedagógicas) tanto quanto falam visto que eles tem vontade de aprender e de solucionar os problemas".

Por outro lado, um professor que ministra disciplinas na área específica relatou que "o curso de Licenciatura em Física do IF Sertão PE, Campus Petrolina, dá maior ênfase na área de Pesquisa em detrimento do Ensino e, desse modo, deixa a formação e/ou prática docência de lado (em segundo plano)". Por fim, outro professor da área de exatas ainda ressaltou que no Campus Petrolina o curso de Licenciatura em Física “valoriza mais o aspecto ‘técnico' em relação ao 'ensino' porque a maioria dos professores que ministram aulas na área de exatas não são Licenciados e sim Bacharéis em Física", todavia, "atualmente o curso está tentando trazer um viés mais para a área pedagógica e para a formação de professores, porém, isso ainda é um desafio".

\section{Considerações Finais}

Nesta experiência vivenciada com a colaboração de professores da área pedagógica e exatas do curso de Licenciatura em Física, percebe-se que o trabalho docente realizado em sala de aula professores nos cursos de Licenciatura do IF Sertão PE, Campus Petrolina, é influenciado pelos conhecimentos adquiridos durante a sua formação profissional. Foi possível perceber também alguns dos professores que ministram aulas no curso de Licenciatura em Física possuem formação em Bacharelado em Física e não Licenciatura esse tipo de formação parece influenciar os estudantes de modo a valorizar mais os conteúdos da área de exatas em detrimento dos conteúdos da área pedagógica.

\section{Referências}

BRASIL. Parâmetros Curriculares Nacionais. Secretaria de Educação Fundamental. Brasília, 1999. CANDAU, V. M. (org). Magistério: construção cotidiana. Petrópolis: Vozes, 1997.

MACEDO, R. S. Etnopesquisa crítica, etnopesquisa-formação. Brasília: Liber Livro, 2009.

SHIGUNOV, A. N; MACIEL, L. S. B. Reflexões sobre a formação de professores. Coleção Magistério: Formação e trabalhos pedagógicos. Campinas, SP: Papirus, 2002. 